\title{
Optimization of DNA extraction and amplified fragment length polymorphism (AFLP) analysis of pomegranate (Punica granatum L.)
}

\author{
Maryam Moslemi $^{1 \star}$, Mehdi Zahravi ${ }^{2}$, Younes Sharghi ${ }^{1}$ and Gholamreza Bakhshi Khaniki ${ }^{3}$ \\ ${ }^{1}$ Department of Agriculture, Islamic Azad University, Islam Shahr Branch, Tehran, Iran. \\ ${ }^{2}$ National Plant Gene Bank of Iran, Karaj, Iran. \\ ${ }^{3}$ Department of Biology, Payame Noor University, Tehran, Iran.
}

Accepted 31 July, 2013

\begin{abstract}
Pomegranate (Punica granatum L.) is a plant rich in polysaccharides, polyphenols and secondary metabolites, which makes it difficult to obtain high quality DNA. The present study reports a quick, simple and inexpensive method to isolate genomic DNA suitable for amplified fragment length polymorphism (AFLP) analysis and other PCR-based applications. This method is a modification of a protocol described by Doyle and Doyle (1990). It is a cetyl trimethyl ammonium bromide (CTAB)-based protocol modified by the use of potassium acetate (KoAc) and polyvinylpyrrolidone (PVP) to remove polyphenols and polysaccharides and a high concentration of $\beta$-mercaptoethanol to reduce oxidation. Moreover, the final optimized protocol was then compared with three different methods, which are routinely used for many plant species. The results show that our modified CTAB protocol produced a high yield (>500 ng/ul) of good-quality DNA $\left(A_{260} / A_{280}>1.8\right)$ compared to the other three methods. The DNA purity was further confirmed by complete digestion with EcoRI and Msel enzymes. The modified CTAB protocol used in this study could be a useful protocol for extraction of high quality DNA not only for pomegranate but also for other plants rich in polysaccharides, polyphenolices and secondary metabolites. Using this method, DNA was extracted from 67 accessions of pomegranate. The DNA was then used for AFLP analysis. To optimize the AFLP protocol, the effects of $\mathrm{MgCl}_{2}$ concentration during selective amplification, the dilution level of pre-amplified DNA and the cycle number used in the preamplification were studied. After optimization of the reaction conditions, AFLP was used to study genetic diversity among Iranian pomegranate accessions.
\end{abstract}

Key words: Pomegranate, DNA extraction, amplified fragment length polymorphism (AFLP), secondary metabolites.

\section{INTRODUCTION}

Pomegranate (Punica granatum L.), a species in the Punicaceae family, is a fruit-bearing deciduous shrub or small tree growing to between 5 and $8 \mathrm{~m}$ tall. It is native to Iran and perhaps some surrounding areas (Stover and Mercure, 2007), and that is spread from Iran to other areas (Levin, 1994). Iran is center of pomegranate diversity. About 800 accessions of pomegranate originating from different provinces of Iran have been gathered in Yazd pomegranate collection. Germplasm collections can only be exploited in breeding programs after they are properly analyzed. Molecular marker techniques based on PCR, such as random amplified polymorphic DNA (RAPD) (Williams et al., 1990), inter simple sequence repeat (ISSR) (Zietkiewicz et al., 1994) and amplified 
Table 1. List of pomegranate accessions used in this study.

\begin{tabular}{lllll}
\hline \multirow{2}{*}{ Accession name } & \multirow{2}{*}{ Population } & \multicolumn{3}{c}{ Main characteristic } \\
\cline { 3 - 5 } & Markazi & Taste & Peel color & Aril color \\
\hline Tabestani & Markazi & Sweet & Pink & Red \\
Alak Shirin & Isfahan & Sour & Red & Red \\
Torsh Zoodras & Isfahan & Sweet-Sour & Red & Pink \\
Malas Shahvar & Isfahan & Sour & White & Pink \\
Anbari Riz & Yazd & Sweet & Red & Red \\
Bazri Marvast & Yazd & Sour & Red & Red \\
Daneh Ghermez Harati & Kerman & Sour & White & Pink \\
Jari Poost Sefid & Kerman & Sweet & Red & Red \\
Shahi Daneh Ghermez & Kerman & Sour & Red & Red \\
Torsh Mahani & Kerman & Sweet & Red & Red \\
Shirin Hasteh Riz & Saveh & Sweet & Black & White \\
Poost Siyah Saveh & Saveh & Sour & White & Pink \\
Torsh Poost Sefid Saveh & Saveh & Sour & Red & Red \\
Sandani Saveh Torsh & Fars & Sour & Black & White \\
Mesri Torsh kazeron & & & & \\
\hline
\end{tabular}

fragment length polymorphism (AFLP) (Vos et al., 1995) are powerful tools for plant breeding and genetic analysis. Among different marker systems available at present, AFLP is a DNA fingerprinting method with a high reproducibility; covering a great number of genome loci in one analysis. Due to its reproducibility and its powerfulness, this tool has been widely used for the characterization and genetic analysis of many plants (Vos et al., 1995). AFLP technique requires isolation of DNA with high purity for restriction digestion. Isolation of DNA free of polysaccharides, polyphenols and various secondary metabolites such as alkaloids, flavonoids and tannins is most essential because these compounds can irreversibly bind to nucleic acids during extraction steps (Varadarajan and Prakash, 1991; Mishra et al., 2008).

Pomegranate contains exceptionally high amounts of polysaccharides, secondary metabolites and polyphenols including mainly ellagitannin, gallotannin, and anthocyanin which interfere with DNA isolation procedure. In their oxidized forms, polyphenols covalently bind to DNA, giving it a brown color and making it useless for most research applications (Aljanabi et al., 1999). There are several DNA extraction protocols for high polyphenol and polysaccharide containing plant species (Ghaffari et al., 2011; Abd-Elsalam et al., 2011; Wang, 2010; SanchezHernandez and Gaytan-Oyarzun, 2006), but none of these are applicable to all plants. Since plants contain high amounts of many different substances, it is unlikely that just one DNA extraction protocol is suitable for all plants (Loomis, 1974).

In pomegranate, several DNA extraction methods have been successfully used (Pirseyedi et el., 2010; Hasnaoui et al., 2010; Sarkhosh et al., 2006). However, these methods are not useful for AFLP analysis. Therefore, in this study, we reported a rapid, simple and inexpensive protocol for isolation of high-quality DNA from pomegranate that can be used for AFLP analysis and other PCR-based applications. Furthermore, the final optimized protocol was then compared with three different methods which are routinely used for many plant species. This is the first report focusing on optimization of DNA extraction for AFLP analysis of pomegranate.

\section{MATERIALS AND METHODS}

Plant material consisted of young leaves of adult trees sampled from different geographic populations. These were collected from Yazd pomegranate collection of National Plant Gene, Bank of Iran. In this collection, about 800 accessions of pomegranate originating from the different populations of Iran were gathered. In the present study, the number of plants tested per population varied from one to four (Table 1). Leaves were frozen in liquid nitrogen and stored at $-80^{\circ} \mathrm{C}$ for future use.

\section{DNA extraction}

DNA was extracted using the cetyl trimethyl ammonium bromide (CTAB) procedure described by Doyle and Doyle (1990) with some modifications. Briefly, Young leaves $(100 \mathrm{mg}$ ) were ground to a fine powder in liquid nitrogen and mixed with $500 \mu$ l of extraction buffer (3\% CTAB; 100 mM Tris-HCl, pH 8.0; 20 mM EDTA, pH 8.0; $1.3 \mathrm{M}$ $\mathrm{NaCl} ; 4 \%$ polyvinylpyrrolidone; $2 \% \quad \beta$-mercaptoethanol). Samples were incubated at $65^{\circ} \mathrm{C}$ for $20 \mathrm{~min}$, subsequently, washed with an equal volume of chloroform/isoamylalcohol (24:1), and centrifuged at $12000 \mathrm{rpm}$ for $10 \mathrm{~min}$. The supernatant was mixed with $200 \mu \mathrm{l}$ potassium acetate (koAc) and $500 \mu \mathrm{l}$ of cold isopropanol carefully and cooled for 15 min and the DNA was pelleted by centrifugation at $12000 \mathrm{rpm}$ for $15 \mathrm{~min}$. Pellets of DNA were then washed with $70 \%$ ethanol twice, dried and dissolved in $200 \mu$ of TE buffer (10 $\mathrm{mM}$ Tris- $\mathrm{HCl}, \mathrm{pH}$ 8.0, 1 mM EDTA, pH 8.0) and extracted DNA was stored at $-20^{\circ} \mathrm{C}$ for later use. 


\section{Comparison analysis with other DNA extraction protocols}

The DNA extracted with modified CTAB protocol was compared with three different methods. In Method I, genomic DNA was extracted using the DNeasy Plant Mini Kit (Qiagen) according to the manufacturer's instructions; this system uses advanced silica-gel membrane technology for isolation of total DNA without phenol, chloroform or ethanol precipitation. The buffer system allows selective binding of DNA to a membrane. In Method II, DNA was extracted using the Sodium dodecyl sulphate (SDS) mini preparation method of Dellaporta et al. (1983). In Method III, DNA was extracted by the method described by Lodhi et al. (1994).

\section{DNA quantification}

The yield of the DNA samples was determined by measuring the absorbance at 260 and $280 \mathrm{~nm}$ in a UV Spectrophotometer and the purity of the DNA was then determined by calculating the ratio of absorbance at $260 \mathrm{~nm}$ to that of $280 \mathrm{~nm}\left(A_{260} / A_{280}\right)$. DNA concentration and purity was also determined by running the extracted genomic DNA samples on $1 \%$ agarose gel using $0.5 \times$ TAE buffer (10 mM Tris- $\mathrm{HCl}$ and $1 \mathrm{mM}$ EDTA, pH. 8.0). A DNA molecular weight size marker was used on each gel. The gels were stained with ethidium bromide and visualized under UV fluorescence.

\section{Optimization of AFLP reaction}

For optimization of AFLP reaction, factors like $\mathrm{MgCl}_{2}$ concentration during selective amplification, the dilution level of pre-amplified DNA and the cycle number used in the pre-amplification were tested. Genomic DNA (50 to $100 \mathrm{ng}$ ) was digested with $5 \mathrm{U}$ each of EcoRI and Tru9l (isoschizomer of Msel) (Fermentas) restriction enzymes in a $40 \mu$ volume and this reaction was incubated at $37^{\circ} \mathrm{C}$ for $10 \mathrm{~h}$, followed by incubation at $65^{\circ} \mathrm{C}$ for $15 \mathrm{~min}$ for denature of the restriction enzymes. Digested DNA fragments were then legated with 5 pmol of EcoRI adapter, $50 \mathrm{pmol}$ of Msel adapter and $1 \mathrm{U}$ T4 DNA ligase (Fermentas) at room temperature for $4 \mathrm{~h}$ in a final volume of $28 \mu \mathrm{l}$. The mixture was then diluted 10 -fold with sterile distilled water. Pre-amplification PCR reaction was performed using primers carrying no selective nucleotide, pre-amplification reaction containing: $4 \mu \mathrm{l}$ of $1: 10$ diluted restriction-ligation mixture, $0.6 \mu \mathrm{M}$ of each pre-amplification primer, $1 \times \mathrm{PCR}$ reaction buffer, $5 \mathrm{mM} \mathrm{MgCl}_{2}$, $0.2 \mathrm{mM}$ dNTPs and $1 \mathrm{U}$ Taq DNA polymerase in a volume of $28 \mu \mathrm{l}$. The mixture was amplified in a Bio-Rad thermocycler using the following profiles: $94^{\circ} \mathrm{C}$ for $30 \mathrm{~s}, 56^{\circ} \mathrm{C}$ for $60 \mathrm{~s}$ and $72^{\circ} \mathrm{C}$ for $60 \mathrm{~s}$ with varying cycle numbers $(15,20$ and 25 cycles). Pre-amplified DNA was checked for the presence of smear of fragment by $1.5 \%$ agarose gel electrophoresis, the pre-amplification products were then diluted to various concentrations $(10,20$, and 50 - fold) to optimize the selective amplification. The selective amplification was performed using the EcoRI and Msel primers with three selective nucleotides at $3^{\prime}$ ends. Selective amplification reaction included $4 \mu \mathrm{l}$ of diluted pre-amplified DNA, $0.75 \mu \mathrm{M}$ of each primer combination, $1 \times \mathrm{PCR}$ reaction buffer, different $\mathrm{MgCl}_{2}$ concentrations (2, 3.2 and 4 $\mathrm{mM}), 0.3 \mathrm{mM}$ dNTPs and $1 \mathrm{U}$ Taq DNA polymerase in a volume of $20 \mu \mathrm{l}$. The reaction was performed following the profile: 1 cycle of $94^{\circ} \mathrm{C}$ for $30 \mathrm{~s}, 65^{\circ} \mathrm{C}$ for $30 \mathrm{~s}$ and $72^{\circ} \mathrm{C}$ for $60 \mathrm{~s}$, then 15 cycles of $94^{\circ} \mathrm{C}$ for $30 \mathrm{~s}, 65^{\circ} \mathrm{C}$ for $30 \mathrm{~s}$ (with decreasing ramp of $0.7^{\circ} \mathrm{C}$ each cycle) and $72^{\circ} \mathrm{C}$ for $60 \mathrm{~s}$ followed by 25 cycles of $94^{\circ} \mathrm{C}$ for $30 \mathrm{~s}$, $56^{\circ} \mathrm{C}$ for $30 \mathrm{~s}, 72^{\circ} \mathrm{C}$ for $60 \mathrm{~s}$ and a final extension of $72^{\circ} \mathrm{C}$ for 10 $\min$.

\section{Gel electrophoresis and silver staining}

The final PCR products were mixed with an equal volume of loading buffer composed of $99 \%$ formamide, $10 \mathrm{mM}$ EDTA $\mathrm{pH} 8,0.1 \%$ xylene cyanole and $0.1 \%$ bromophenol blue; the mixture was denatured at $95^{\circ} \mathrm{C}$ for $5 \mathrm{~min}$ and cooled immediately on ice. $3 \mu \mathrm{l}$ of each sample was loaded on a pre-warmed $6 \%$ polyacrylamide gel running with $1 \times$ TBE buffer, electrophoresis was carried out at $80 \mathrm{~W}$ and $50^{\circ} \mathrm{C}$ for $1 \mathrm{~h}$ until the forward-running dye reached the end of the gel, followed by silver staining using the procedure below: after electrophoresis, the gel was fixed in $1 \%$ acetic acid for $15 \mathrm{~min}$. After rinsing in distilled water, the gel was stained with a $0.2 \%$ silver nitrate solution for $20 \mathrm{~min}$. The stained gel was rinsed twice with distilled water and was placed in a developing solution composed of $3 \%$ sodium carbonate and $0.06 \%$ formaldehyde until solution became dark. It was placed again in the developing solution until the bands became visualized; the development was stopped with $1 \%$ acetic acid and after rinsing in distilled water, the gel was dried and was scanned.

\section{RESULTS AND DISCUSSION}

\section{Evaluation of quantity and quality of DNA}

In pomegranate, several molecular markers have been used for genetic studies (Melgarejo et al., 2009; Sarkhosh et al., 2006; Pirseyedi et al., 2010; Jbir et al., 2008; Yuan et al., 2007a). Since pomegranate is a plant rich in polyphenols and polysaccharides, and these inhibitors interfere with Taq DNA polymerase and restriction enzymes, their removal can have a great impact on successful molecular-based studies and PCR reaction. CTAB based extraction methods are frequently used for DNA isolation from plant tissues. The extraction technique of Doyle and Doyle has been applied successfully in horticulture and fruit trees, such as, apricot (Yuan et al., 2007b), plum (llgin et al., 2009), and grape (Lodhi et al., 1994).

In the present study, significant changes to the method reported by Doyle and Doyle (1990) consisted of higher CTAB and $\beta$-mercaptoethanol concentrations, use of potassium acetate (KoAc) and polyvinylpyrrolidone (PVP). Detergents like CTAB and PVP remove polyphenols and polysaccharides, while the $\beta$-mercaptoethanol reduces oxidation (De la Cruz et al., 1997). PVP has been used to remove polyphenols from leaf tissues in several protocols (Lodhi et al., 1994; Doyle and Doyle, 1987; Aljanabi et al., 1999; Kim et al., 1997). PVP or PVPP (polyvinylpolypyrrolidone) efficiently forms complex hydrogen bonds with polyphenolic compounds and alkaloids, which can be separated from DNA by centrifugation (Maliyakal, 1992). However, in some cases, brown color of DNA in our study was not lost with PVP. Only when potassium acetate has been applied, removing of phenolic compounds was possible.

In this study, the modified CTAB protocol resulted in the greatest yield of DNA. A lesser amount of DNA was extractable from the Qiagen commercial kit. The methods of Lodhi et al. (1994) and Dellaporta et al. (1983) produced extremely little DNA. The results of the quantification are displayed in Table 2. The $A_{260} / A_{280}$ absorbance ratios varied between 1.13 and 2.03 for DNA extracted with Dellaporta et al. (1983) and modified CTAB protocol respectively; indicating the highest and lowest protein contamination among the four methods, respectively. 
Table 2. Yield and purity of DNA obtained by four extraction methods.

\begin{tabular}{lcc}
\hline Extraction method & $\boldsymbol{A}_{\mathbf{2 6 0}} / \boldsymbol{A}_{\mathbf{2 8 0}}$ ratio & DNA yield $(\mathbf{n g} / \mathbf{\mu l})$ \\
\hline Modified CTAB & 2.03 & 532.47 \\
Qiagen DNeasy & 1.49 & 295.84 \\
Lodhi et al. (1994) & 1.14 & 3.38 \\
Dellaporta et al. (1983) & 1.13 & 2.03 \\
\hline
\end{tabular}

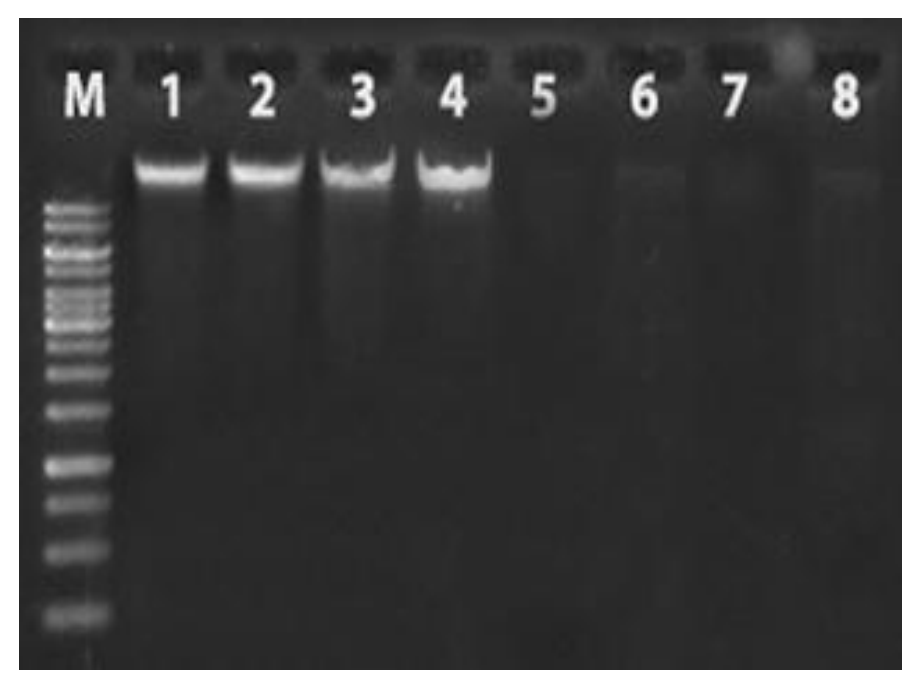

Figure 1. Genomic DNA extracted by the following four different protocols: Lanes 1 and 2, the modified CTAB; lane 3 and 4, Qiagen DNeasy Plant Mini Kit; lanes 5 and 6, Lodhi et al., (1994) and lanes 7 and 8, Dellaporta et al., (1983). Lane M represents the Molecular weight marker-GeneRuler ${ }^{\mathrm{TM}} 1 \mathrm{~kb}$ DNA ladder.

When DNA is extracted, protein frequently remains in the DNA solution. Protein is tightly bound to DNA, and complete removal of protein is not always possible. Generally, the peak of UV absorption is at $260 \mathrm{~nm}$ for DNA and at $280 \mathrm{~nm}$ for protein. Thus, when a solution contains both DNA and protein, absorbance at $260 \mathrm{~nm}$ is mainly due to the DNA present, and absorbance at $280 \mathrm{~nm}$ is due to protein. The expected ratios for extracted DNA samples should range from 1.7 to 2.0 (Miller et al., 2009). DNA obtained using the modified CTAB protocol and isolation kit appeared on the agarose gel as a single band of high molecular weight (greater than 10,000 base pairs) and there is little or no evidence of degradation, shearing, or RNA contamination. Lodhi et al. (1994) and Dellaporta et al. (1983) methods failed to produce a visible band of genomic DNA (Figure 1).

Products of digestion with EcoRI and Msel restriction enzymes showed that DNA obtained by the modified CTAB protocol was completely digested (Figure 2). So these results confirmed that the extracted DNA by the modified CTAB protocol has a better quality and quantity compare with the other three methods. Using our modified CTAB protocol, high quality DNA samples from different populations of pomegranate consisting of 67

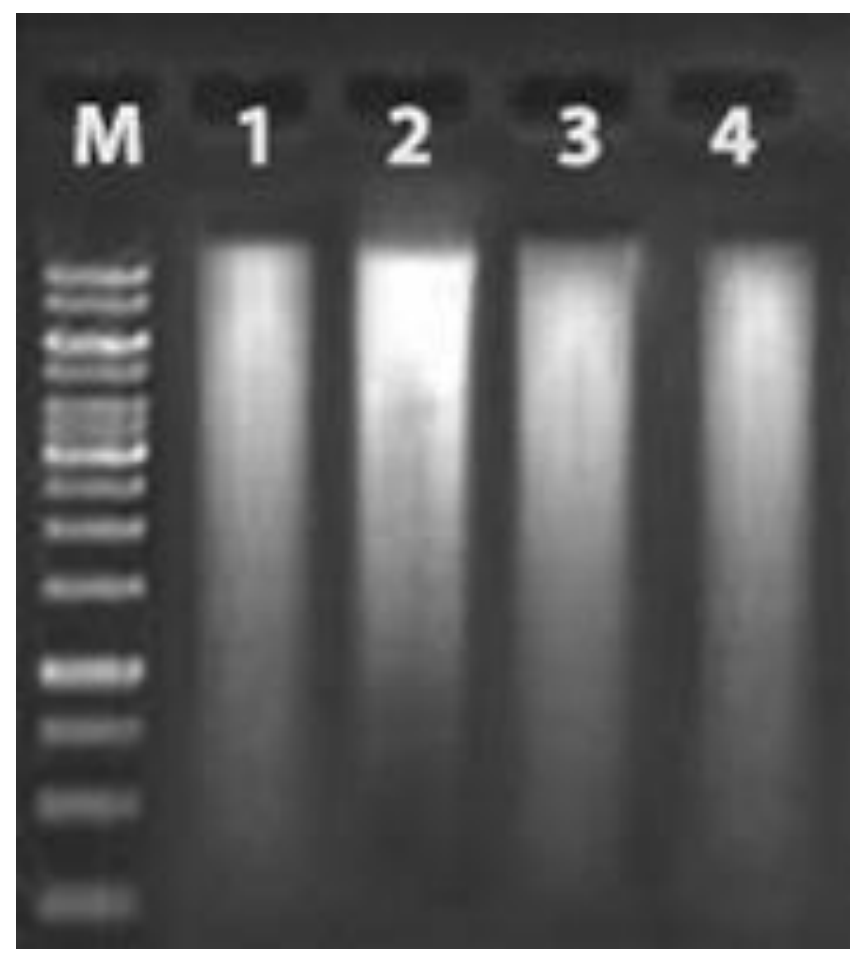

Figure 2. Restriction digestion of DNA isolated by the modified CTAB protocol. Lanes 1 to 4 show genomic DNA from four accessions of pomegranate digested with EcoRI/Msel enzymes. Lane M shows $1 \mathrm{~kb}$ DNA ladder.

accessions were extracted by a single person in less than one day. The obtained DNA was suitable for applications involving restriction enzyme digestion or PCR-based applications.

\section{Optimization of AFLP reaction}

The extracted DNA with our modified protocol was subjected to AFLP analysis. Optimization of AFLP reaction is essential for band generation and reproducibility of the results. Therefore, we examined the effects of different $\mathrm{MgCl}_{2}$ concentrations during selective amplification, the dilution level of pre-amplified DNA and the cycle number used in the pre-amplification on the quality of AFLP profiles. Figure 3 shows the effects of different $\mathrm{MgCl}_{2}$ concentrations $(2,3.2$ and $4 \mathrm{mM})$ and the dilution 
A

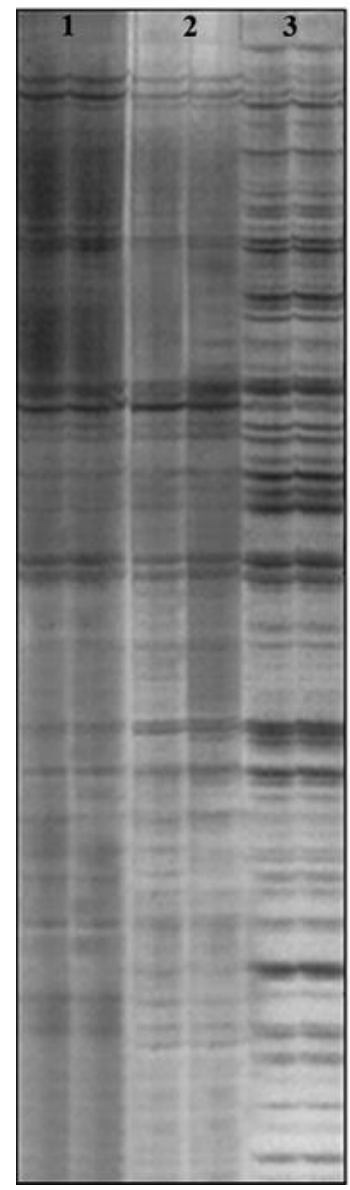

B

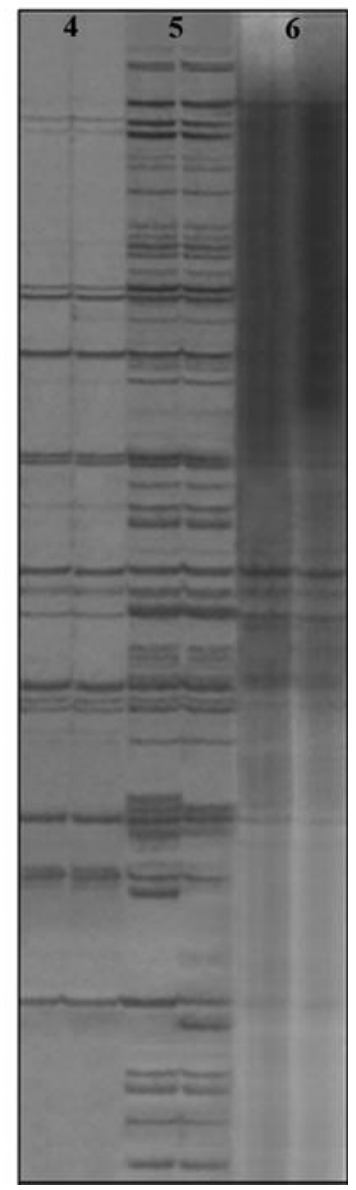

Figure 3. Effects of dilution level of pre-amplified DNA (A) and $\mathrm{MgCl}_{2}$ concentration (B) on the AFLP fingerprint. Lanes 1-3 represent different dilutions of DNA (10-, 20- and 50-fold, respectively) and lanes 4-6 represent different $\mathrm{MgCl}_{2}$ concentrations (2, 3.2 and 4 $\mathrm{mM}$ respectively).

level of pre-amplified DNA (10, 20, and 50-fold) on the quality of AFLP profiles. In higher DNA concentrations, there was a high background smear due to competitive inhibition between fragments during PCR that completely disappears in low concentrations so that the bands were scoroble. This background smear was also present in higher $\mathrm{MgCl}_{2}$ concentrations. Furthermore, decrease in pre-amplification cycle numbers resulted in poor amplification. The use of 50 -fold dilution, $3.2 \mathrm{mM} \mathrm{MgCl}_{2}$ and 25 cycles of pre-amplification resulted in the best resolution and clarity of profiles (Figure 4). After optimization of the reaction conditions, polymorphism among Iranian pomegranate accessions was studied using different primer pairs.

\section{ACKNOWLEDGEMENTS}

This work was supported by National Plant Gene Bank of

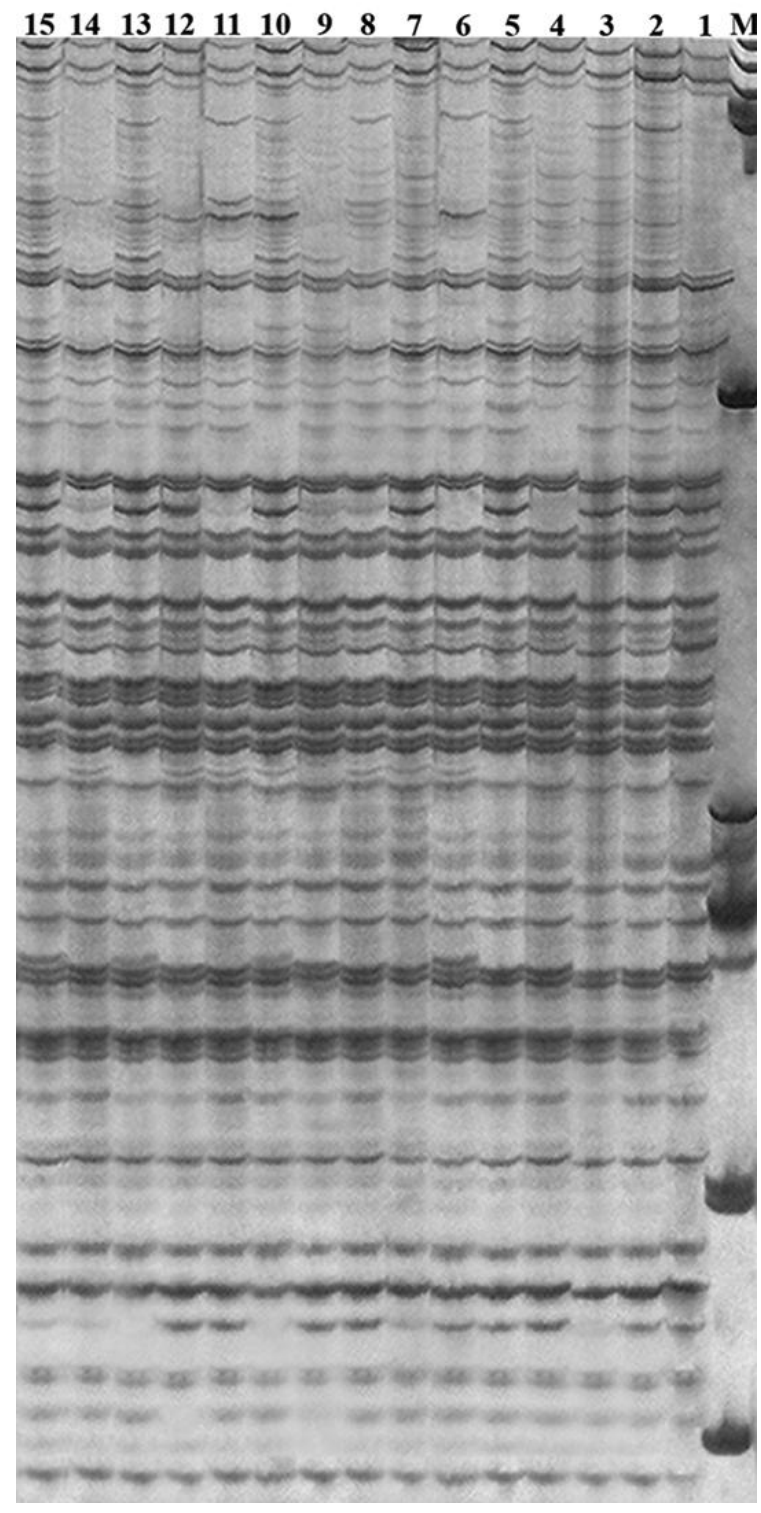

Figure 4. AFLP profiles of pomegranate on $6 \%$ polyacrilamide gel using DNA isolated by the modified CTAB protocol. The selective primer combination used was E-AAC/M-CAC. Lanes 1-15 represents accessions as described in Table 1, M is the 50 bp DNA ladder.

Iran (project number: 310012140084145$)$. We would like to thank all those who assisted in the field collection and laboratory processing of samples for this project.

\section{REFERENCES}

Abd-Elsalam K, Bahkali A, Moslem M, E. Amin O, Niessen L (2011). An Optimized Protocol for DNA Extraction from Wheat Seeds and LoopMediated Isothermal Amplification (LAMP) to Detect Fusarium graminearum Contamination of Wheat Grain. Int. J. Mol. Sci. 12: 3459-3472.

Aljanabi SM, Forget L, Dookun A (1999). An improved and rapid protocol for the isolation of polysaccharide- and polyphenol-free sugarcane DNA. Plant Mol. Biol. Rep. 17: 1-8. 
De la Cruz M, Ramirez F, Hernandez H (1997). DNA isolation and amplification from cacti. Plant Mol. Biol. Rep. 15: 319-325.

Dellaporta SL, wood J, Hicks JB (1983). A plant DNA minipreparation. Plant Mol. Biol. Rep. 1: 19-21.

Doyle JJ, Doyle JL (1987). A rapid DNA isolation procedure for small quantities of fresh leaf tissue. Phytochem. Bull. 19: 11-15.

Doyle JJ, Doyle JL (1990). Isolation of plant DNA from fresh tissue. Focus 12: 13-15.

Ghaffari S, Hasnaoui N , Ferchichi A (2011). Rapid, High Quality DNA Isolation from Tunisian Grapevine (Vitis vinifera L.) Cultivars and Optimization of the RAPD Marker Technique. Rom. Biotech. Lett. 16(1): 5881-5890.

Hasnaoui N, Mars M, Chibani J, Trifi M (2010). Molecular Polymorphisms in Tunisian Pomegranate (Punica granatum L.) as Revealed by RAPD Fingerprints. Divers. 2: 107-114.

Ilgin M, Kafkas S, Ercisli S (2009). Molecular characterization of plum cultivars by AFLP markers. Biotechnol. Biotechnol. Eq. 23: 11891193.

Jbir R, Hasnaoui N, Mars M, Marrakchi M, Trifi M (2008). Characterization of Tunisian pomegranate (Punica granatum L.) cultivars using amplified fragment length polymorphism analysis. Sci. Hort. 115: 231-237.

Kim CS, Lee CH, Shin JS, Chung YS, Hyung NI (1997). A simple and rapid method for isolation of high quality genomic DNA from fruit trees and conifers using PVP. Nucleic Acids Res. 25: 1085-1086.

Levin GM (1994). Pomegranate (Punica granatum L.) plant genetic resource in Turkmenistan. Plant Genet. Resour. Newsl. 97: 31-36.

Lodhi MA, Ye GN, Weeden NF, Reisch BI (1994). A simple and efficient method for DNA extraction from grapevine cultivars and Vitis species. Plant Mol. Biol. Rep. 12: 6-13.

Loomis WD (1974). Overcoming problems of phenolics and quinones in the isolation of plant enzymes and organelles. Meth. Enzymol. 31: 528-544.

Maliyakal EJ (1992). An efficient method for isolation of RNA and DNA from plants containing polyphenolics. Nucleic Acids Res. 20: 2381.

Melgarejo P, Martinez JJ, Hernandez F, Martinez R, Legua P, Oncina R, Martinez-Murcia A (2009). Cultivar identification using 18S-28S rDNA intergenic spacer-RFLP in pomegranate (Punica granatum L.). Sci. Hort. 120: 500-503.

Miller NJ, Guillemaud T, Giordano R, Siegfried BD, Gray ME, Meinke LJ, Sappington TW (2009). Genes, gene flow and adaptation of Diabrotica virgifera virgifera. Agric. For. Entomol. 11: 47-60.

Mishra KM, Rani SN, Ram AS, Sreenath HL (2008). A simple method of DNA extraction from coffee seeds suitable for PCR analysis. Afr. J. Biotechnol. 7: 409-413.

Pirseyedi SM, Valizadehghan S, Mardi M, Ghaffari MR, Mahmoodi M, Zahravi M, Zeinalabedini M, Khayam Nekoui SM (2010). Isolation and characterization of novel microsatellite markers in pomegranate (Punica granatum L.). Int. J. Mol. Sci. 11: 2010-2016.
Sanchez-Hernandez C, Gaytan-Oyarzun JC (2006). Two mini-preparation protocols to DNA extraction from plants with high polysaccharide and secondary metabolites. Afr. J. Biotechnol. 5: 18641867.

Sarkhosh A, Zamani Z, Fatahi R, Ebadi A (2006). RAPD markers reveal polymorphism among some Iranian Pomegranate (Punica granatum L.) genotypes. Sci. Hort. 111: 24-29.

Stover E, Mercure EW (2007). The pomegranate: a new look at the fruit of paradis. Hort. Science 42: 1088-1092.

Varadarajan CS, Prakash CS (1991). A rapid and efficient method for the extraction of total DNA from the sweet potato and its related species. Plant Mol. Biol. Rep. 9: 6-12.

Vos P, Hogers R, Bleeker M, Reijans M, van de Lee T, Hornes M, Frijters A, Pot J, Peleman J, Kuiper M, Zabeau M (1995). A new technique for DNA fingerprinting. Nucleic Acids Res. 23: 4407-4414.

Wang XM (2010). Optimization of DNA isolation, ISSR-PCR system and primers screening of genuine species of rhubarb, an important herbal medicine in China. J. Med. Plants Res. 4(10): 904-908.

Williams JGK, Kubelik AR, Livak KJ, Rafalski JA, Tingey SV (1990). DNA polymorphisms amplified by arbitrary primers are useful as genetic markers. Nucleic Acids Res. 18: 6531-6535.

Yuan Z, Yin Y, Qu J, Zhu L, Li Y (2007a). Population genetic diversity in Chinese pomegranate (Punica granatum L.) cultivars revealed by fluorescent-AFLP markers. J. Genet. Genomics 34: 1061-1071.

Yuan Z, Chen X, He T, Feng J, Feng T, Zhang C (2007b). Population genetic structure in apricot (Prunus armeniaca L.) cultivars revealed by fluorescent-AFLP markers in Southern Xinjiang, China. J. Genet. Genomics 34: 1037-1047.

Zietkiewicz E, Rafalski A, Labuda D (1994). Genome fingerprinting by simple sequence repeat (SSR)-anchored polymerase chain reaction amplification. Genomics 20: 176-183. 